\title{
Debt Shifting and Thin-Capitalization Rules - German Experience and Alternative Approaches
}

DOI 10.1515/ntaxj-2015-0002

Received October 20, 2014; accepted March 1, 2015

\begin{abstract}
This paper presents the general design of thincapitalization rules and summarizes the economic effects of such rules as identified in theoretical models. We review empirical studies providing evidence on the experience with (German) thin-capitalization rules as well as on the adjustment of German multinationals to foreign thin-capitalization rules. Special emphasis is given to the development in Germany, because Germany went a long way in limiting interest deductibility by enacting a drastic change in its thin-capitalization rules in 2008 , and because superb German data on multinational finance allows for testing several aspects consistently. We then discuss the experience of the Nordic countries with thincapitalization rules. Briefly reviewing potential alternatives as well, we believe that the arm's-length principle is administratively too costly and impracticable, whereas we argue that controlled-foreign-company rules might be another promising avenue for limiting internal debt shifting. Fundamental tax reforms towards a system with either "allowance for corporate equity" (ACE) or a "comprehensive business income tax" (CBIT) should also eliminate any thin-capitalization incentive.
\end{abstract}

\section{Introduction}

In recent years, thin capitalization of firms and international debtshifting have gained massive attention both among policy makers and in the economic literature. The standard effect of thin capitalization, that is replacing eq-

Dirk Schindler: Norwegian School of Economics, NoCeT and CESifo; Norwegian School of Economics, Department of Accounting, Auditing and Law, Helleveien 30, 5045 Bergen, Norway; Email: Dirk.Schindler@nhh.no; Tel.: +47-55959628.

Martin Ruf: Eberhard Karls Universität Tübingen and NoCeT; Lehrstuhl für BWL, insb. International Business Taxation, Wirtschafts- und Sozialwissenschaftliche Fakultät, Eberhard Karls Universität Tübingen, Nauklerstr. 47, 72074 Tübingen; Email: Martin.Ruf@uni-tuebingen.de. uity by tax-preferred external debt in order to benefit from the external debt tax shield, ${ }^{1}$ has been well-known for decades. Facilitated by ongoing integration of formerly national financial markets and the rapidly growing share of multinational companies in worldwide trade, the international component of thin capitalization, known as international debt shifting, has become more and more worrisome, however.

It is well known that multinationals use international debt shifting to save tax payments by utilizing differences in national tax rates and preferential tax rules (e.g., Desai et al. (2004); Mintz and Weichenrieder (2010)). For external debt shifting, there is evidence that multinationals excessively load those affiliates generating high net tax savings (i.e., being located in high-tax countries) with external debt. On the other hand, to keep overall bankruptcy costs in check, the use of external debt in affiliates with low tax savings (i.e., in low-tax countries) is reduced. In total, this allows for higher tax savings than in comparable domestic firms (see Huizinga et al. (2008); Møen et al. (2011)). For internal debt shifting (a strategy of borrowing and lending among related affiliates of a multinational), the mechanism at play is to deduct interest in high-tax countries and to earn interest in low-tax countries in such a way that the tax savings in high-tax countries exceed the increased tax liability in low-tax countries. To maximize the internal debt tax shield, it is optimal to set up an internal bank in the lowest-taxed affiliate, which provides all other affiliates with internal debt, i.e., with intra-company loans (see, e.g., Mintz and Smart (2004); Schindler and Schjelderup (2012)).

In particular, non-regulated internal debt shifting can be used as a money machine generating tax-arbitrage profits as long as there is positive taxable income. There-

1 The common term 'debt tax shield' labels tax savings that are generated by the deductibility of interest payments on debt from the corporate tax base. "External debt tax shield" refers to the tax savings generated by loans from the external capital-market, that is, by borrowing from unrelated, third parties. "Internal debt tax shield" represents tax savings due to tax-deductible internal borrowing from related affiliates. 
fore, most countries have implemented thin-capitalization rules to curb tax-driven debt financing that leads to interest deductions being excessive from point of view of tax authorities, and to protect their corporate tax bases. ${ }^{2}$ The OECD encourages such implementations in its recent action plan against base erosion and profit shifting (OECD (2013, action 4)). Germany is a case in point and has more than 20 years of experience with thin-capitalization rules. Discussing Germany thoroughly as a special case is of interest because it has gone very far in restricting interest deductibility in its latest tax reform and now serves as a blueprint for similar reforms in other European countries, examples being Italy, Spain and, since 2014, Norway and Finland. Norway, for instance, introduced a slightly softer version of the German rules that does not restrict external debt. $^{3}$ Furthermore, the available data on German multinationals, that is the MiDi database provided by Deutsche Bundesbank (i.e., the German central bank), is outstanding and allows researchers to empirically test several theoretical predictions.

In this paper, we start out by describing trends in the design of thin-capitalization rules in general and intuitively summarize the economic effects of such regulation that we would expect according to theoretical models of international debt shifting. Thereby, the term "thin capitalization rules" in general encompasses all measures that are intended to restrict tax deductibility of debt, no matter whether they are focusing on internal or total debt and whether they base thresholds on an debt-to-equity ratio or relative to an earnings measure. We then place emphasis on the German development and provide a description of the former and the current German thin-capitalization rules.

Evaluating empirical studies, we find that thincapitalization rules worldwide as well as for the specific case of Germany - consistent with theoretical predictions - are effective in reducing the debt-to-asset ratio. Contrary to theoretical predictions, we do not find clear em-

\footnotetext{
2 Gouthière (2005); Dourado and de la Feria (2008) provide compact overviews on the thin-capitalization regulation in OECD and EU countries, respectively.

3 However, a committee of experts (the so called "Scheel committee") recommended in December 2014 to tighten the regulation and go beyond the German rules even (NOU2014:13 (2014, ch. 8.5)). Sweden also appointed an expert committee for corporate-tax reform options that, in June 2014, proposed to enact a fundamental tax reform by introducing a so-called "Comprehensive Business Income Tax". Apparently, thin capitalization is considered to be a major problem there. See Regeringen (2014) for an official English summary of the concerns and proposals and Lodin (2014) for a comment.
}

pirical evidence for reduced investment because of thincapitalization rules. This may partly be due to there being too few empirical studies investigating the effect of thin-capitalization rules on investment. To some extent, it could also be explained by the fact that multinationals could rely on some loopholes in the regulation (such as, the preference for holding companies) allowing them to work around thin-capitalization rules (see Weichenrieder and Windischbauer (2008, section 5), for details) and leading to the false impression that the regulation has been very effective.

We summarize the recent development in thincapitalization rules in the Nordic countries and point out large analogies and some differences to Germany. Finally, we briefly compare thin-capitalization rules to potential alternatives, such as the arm's length principle; controlled foreign company rules (henceforth CFC rules); and a fundamental tax reform towards either a Comprehensive Business Income Tax (CBIT) or a system with allowance for corporate equity (ACE). Under the arm's-length principle, tax deductibility of internal debt may be denied if the internal financing could not have been conducted with external debt at the same conditions. For curbing debt shifting, the arm's length principle appears to have limited bite and is difficult to enforce. CFC rules deny the tax-exemption principle and trigger an immediate inclusion of 'passive income' earned in low-tax affiliates (e.g., interest income on internal loans to related companies) in the tax base of the headquarters of domestic multinationals. The latter rules are compatible with tax competition, but such CFC rules do not restrict thin-capitalization in domestic affiliates of foreign multinationals, and they adversely affect the competitiveness of domestic multinationals relative to their competitors.

Attractive - and consistent - alternatives for preventing thin capitalization and debt shifting are also to fundamentally change the corporate income tax system to an ACE system, amending interest deductibility with a notional interest deduction for equity (Institute for Fiscal Studies, 1991), or a CBIT, denying tax deductibility of any financing costs (US Department of Treasury, 1992). The introduction of such tax systems needs, however, to take into account several other aspects which cannot be discussed in this paper. We refer instead to De Mooij and Devereux (2011) for a recent overview and further references.

An important caveat, when assessing our findings, is that internal debt need not only serve tax avoidance purposes. There is empirical evidence that affiliates receive internal debt from the headquarters or from other affiliates within a multinational in order to mitigate and overcome capital market imperfections in their host countries. See, 
Table 1: Empirical effects of TC rules on debt-to-asset ratio (DAR) and investment

\begin{tabular}{|c|c|c|c|}
\hline Study & Effect on internal DAR & $\begin{array}{c}\text { Effect on } \\
\text { investment }\end{array}$ & Other results \\
\hline Blouin et al. (2014) & -6.3 percentage points & $\mathrm{n} / \mathrm{a}$ & - \\
\hline Büttner et al. (2012) & decreases & $\mathrm{n} / \mathrm{a}$ & External DAR increases \\
\hline Weichenrieder and Windischbauer (2008) & decreases & no effect & $\begin{array}{l}\text { MNCs use loopholes } \\
\text { in TC legislation }\end{array}$ \\
\hline Overesch and Wamser (2010) & -2.5 percentage points & $\mathrm{n} / \mathrm{a}$ & - \\
\hline Wamser (2014) & -5 percentage points & $\mathrm{n} / \mathrm{a}$ & External DAR increases \\
\hline
\end{tabular}

for example, Büttner et al. (2009); Desai et al. (2004). We implicitly assume that capital markets are perfect except for the debt tax shield and some debt-related agency costs (e.g., costs of financial distress). This should be the case for almost all OECD countries, and internal debt can then be seen as tax-preferred equity serving tax-avoidance purposes only.

The remainder of the paper is organized as follows. Section 2 briefly discusses the international experience with thin-capitalization rules and explains which economic effects should be expected in theory. Section 3 describes the development and the design of German thincapitalization rules since their introduction in 1994 until the present date. Section 4 reviews the empirical evidence on the effectiveness of thin-capitalization rules. In Section 5 , the history of regulating thin capitalization in the Nordic countries is reviewed, while thin-capitalization rules are briefly contrasted with potential alternatives in section 6 . The paper closes with a short summary and conclusion.

\section{Thin-Capitalization Rules: General Design, Trends and Effects}

As reported by (Büttner et al., 2012, section 1), Canada was at the forefront, introducing thin-capitalization rules (henceforth TC rules) in 1971; Australia (in 1987) and the US (in 1989) followed at quite some distance; and implementing TC rules took off between the mid-nineties and 2005, when the share of OECD countries (EU countries) with TC rules increased from less than half (a third) to more than two thirds (three fifths). In the majority of cases, such TC rules are targeting internal debt in multinational companies (henceforth MNCs).

\subsection{Design of Thin-Capitalization Rules and Recent International Development}

The aim of TC rules is to curb tax-driven debt financing that leads to interest deductions being excessive from point of view of tax authorities and to limit tax-revenue losses from international debt shifting (i.e., from shifting income via interest expenses in low-tax countries). In practice, there are two main approaches used in order to achieve this aim: traditional "safe-harbor rules" and "earnings stripping rules". Safe-harbor rules have been the method of choice for many years and focus directly on the capital structure (e.g., the ratio of debt from related parties to equity). Earnings stripping rules became popular in recent years and restrict deductibility of (internal or total) interest expenses relative to firms' profitability. In most cases, both sets of TC rules have analogous effects. ${ }^{4}$

Earnings stripping rules virtually apportion profitability into "returns" on debt and equity. Then, these rules introduce an upper ceiling for the share of earnings that can be qualified as tax deductible interest expenses. The US was first in introducing such a rule and, as from 1989, has denied deductibility of "excessive" interest expenses exceeding $50 \%$ of a company's earnings before interest, taxes, depreciations and amortization (EBITDA) if the internal-debt-to-equity ratio lies above a safe harbor of 1.5:1 and if (excessive) interest is paid to a related party outside the scope of the US income tax. ${ }^{5}$ After an amendment in 1993, third-party debt that is guaranteed by the parent company is also treated as (restricted) internal debt. See, e.g., Knipe et al. (2009). In 2008, Germany followed

4 Dourado and de la Feria (2008, section II.1) qualify safe-harbor rules as "specific TC rules" and label earnings stripping rules "nonspecific TC rules". Furthermore, some authors claim that an earningsstripping rule is not a TC rule, but an approach having similar effects (see for example Dourado and de la Feria (2008)). We find the latter differentiation too semantic, however.

5 Thus, the US combines both approaches, actually. 
and extended the US example. Since then, German tax law has denied deductibility of "excessive interest expenses" (defined as interest expenses above 30\% of a company's EBITDA) from the domestic tax base, but the safe-harbor clause was skipped - see section 3.3. Italy, and recently Portugal, Spain as well as Finland and Norway followed the German example and implemented very similar rules. ${ }^{6}$

The traditional approach of focusing rules directly on the capital structure (i.e., on debt-to-equity ratios) is still more widespread. The majority of countries with TC rules restrict tax deductibility of (internal) debt as soon as a predefined safe-harbor ratio of debt to equity (see, e.g., table 1 in Büttner et al. (2012)) is violated. Such safe-harbor rules do not apply (i.e., do not deny deductibility of interest expenses) as long as the (internal) debt-to-asset ratio remains within the safe-harbor ratio. Many countries focus on internal debt only, some countries restrict the total debt-to-asset ratio. ${ }^{7}$ In 2008, the average safe-harbor ratio of internal debt to equity was 3.4:1 in EU countries (with TC rules). ${ }^{8}$ If the safe-harbor ratio is exceeded, this is taken as an indication that the capital structure is not at arm's length and the TC rules deny interest deductibility for excessive internal debt coming from shareholders with significant influence on the management. ${ }^{9}$ This influence is usually taken as given if direct and indirect voting rights of such a shareholder amount to $25 \%$ of all shares or voting rights (note that for some countries the limit is $50 \%$ or higher). Usually, exemptions for financial institutions apply.

Another common feature of TC rules that were in place until 2004 was that they were only targeted to foreign investment and did not apply to internal finance by domestic investors. In December 2002, however, the European Court of Justice (henceforth ECJ) decided in the so-called "Lankhorst-Hohorst case" that the German TC rules (before 2004) violated the principle of "freedom of establishment". Since the old rules were only targeted at inbound investors and did not apply to German investors, this resulted in discrimination against German companies' loan

6 It is fair to say that, even though Germany is usually perceived as the European pioneer in earnings-stripping rules, it might have been Denmark coming up first with discussions on such rules. The earnings stripping rule in Denmark also has quite some differences compared to the German approach.

7 Another source for differences is whether the safe-harbor rule is using market values, tax values, or accounting values.

8 Own calculations based on Dourado and de la Feria (2008, table 1). 9 In principle, the application of the TC rule can still be waived if the firm can prove that their debt level is at arm's length. This exception clause, however, hardly matters in reality. agreements with non-resident related companies or shareholders relative to loan agreements with resident related companies or shareholders.

This ECJ ruling forced nearly all EU countries to reform their TC rules. One way to cope with the ruling was to exclude companies residing in other EU countries from the application of TC rules. This direction was adopted by, for example, Spain and Portugal. The other avenue, for instance, taken by Germany, was to apply TC rules to both resident and non-resident companies. ${ }^{10} \mathrm{~A}$ radical step was taken by the UK As the only EU country, it abandoned its TC rules from 2004 onwards and has since then relied on the arm's length principle only. In 2010, an additional, complex "World Wide Debt Cap" was introduced in the UK that applies, however, only if the net debt in the UK affiliate exceeds $75 \%$ of worldwide gross debt within the MNC. ${ }^{11}$

\subsection{Economic Effects of Thin-Capitalization Rules}

From theoretical analyses of models on corporate finance, debt shifting, investment behavior and tax competition, it follows that (effective) TC rules will not only affect the financial structure of MNCs and international debt shifting, but also real investment in affiliates of MNCs. It follows as well that such rules are used as an instrument for international tax competition. This subsection presents the main effects that should be expected according to economic theory.

\subsubsection{Debt-to-Asset Ratio and Debt Shifting}

Almost all TC rules intend to curb international debt shifting and are relevant for MNCs only. This is obvious for safeharbor type TC rules directly limiting the tax-deductible level of internal debt, since internal debt, being a taxfavored substitute for equity, should play a meaningful role only in MNCs. It is less obvious for earnings-stripping rules, because these may affect domestic firms, as well. Due to the group clause and the escape clause, however, the earnings stripping rule in place in Germany since 2008 (i.e., the "Zinsschranke") does not effectively apply to do-

10 See, e.g., Dourado and de la Feria (2008, p. 6f) for a brief summary of the Lankhorst-Hohorst case and its implications for TC rules in the EU.

11 See subsection 6.1 for an evaluation of the arm's length principle and Dourado and de la Feria (2008, section 1.3.16) and Ernst \& Young (2014, pp. 1141) for a brief overview of the British system. 
mestic firms, either - as holds true for the specification of the US rule.

While most safe-harbor rules are concerned with internal debt only, earnings stripping rules in principle allow tax authorities to curb international shifting of external debt as well. ${ }^{12}$ Since any potential effect of earnings stripping rules on external debt is analogous to the effect of a safe-harbor rule on internal debt, we focus on internal debt in the following.

For effective TC rules, there are two possibilities: (i) TC rules are perfectly binding or (ii) even effective TC rules offer some leeway. In the first case, perfectly binding implies that there is no way to work around these rules. For safe-harbor rules, this would imply that there is no tax deductibility of (internal) debt as soon as the safe harbor is exceeded and the (internal) debt tax shield drops to (below) zero. In this case, the MNC's optimal internal debt-toasset ratio in the affiliate under a TC rule will be exactly the safe harbor defined in the tax code. Until that ratio is reached, there is a positive debt tax shield and the generated tax savings need not be netted against concealment costs since the latter should be negligible. When the safe harbor is reached, the debt tax shield drops to zero (and marginal concealment costs go to infinity) and any incentive for further thin capitalization vanishes. Any tightening of the $\mathrm{TC}$ rules (e.g., by reducing the safe harbor ratio) will decrease internal and overall debt-to-asset ratios and affiliates under consideration will be more equity-financed, all else equal. Furthermore, the tax rate elasticity of (internal) debt in affiliates facing perfectly binding TC rules is zero, since the debt tax shield is zero and does not respond to tax-rate changes.

In the second case, effective TC rules with some leeway can be partly circumvented, if some tax-engineering effort is exerted. This appears to be the realistic case since all TC rules offer some loopholes (e.g., the preference given to holdings in the former German TC rules), and there exists a large consultancy industry that specializes in facilitating tax avoidance (and finding such loopholes). If there is some leeway in the TC rules, the (internal) debt tax shield remains positive, even if the safe-harbor ratio is exceeded, in other words, even if there is excessive debt financing. However, to preserve tax deductibility of debt beyond this threshold, additional concealment effort is necessary (e.g., hiring of specialized tax consultants) and marginal concealment costs increase substantially. Hence, debt financing and debt shifting become less profitable.

12 See Huizinga et al. (2008); Møen et al. (2011) for theoretical and empirical analyses of external debt shifting.
The reduced net tax savings trigger a reduced debt-to-asset ratio in affiliates under effective TC rules. The tax rate sensitivity of (internal) debt-to-asset ratios will also be reduced, but as the (internal) debt tax shield still reacts to tax-rate changes, the sensitivity remains positive as long as marginal concealment costs do not become prohibitive. See, e.g., Schindler and Schjelderup (2013, section 5) for a formal analysis (including the interplay with interest-rate manipulation).

In sum, effective $\mathrm{TC}$ rules, whether perfectly binding or still offering some leeway, reduce debt-to-asset ratios, limit debt shifting and - for a given level of investment increase tax revenue.

\subsubsection{Real Investment}

As pointed out above, effective TC rules decrease the overall debt-to-asset ratio and increase the share of equity in financing affiliates' capital investment. Since the costs of equity cannot be deducted from the corporate tax base, restricting international debt shifting, and internal debt shifting in particular, increases the effective capital costs (see Hong and Smart (2010); Schindler and Schjelderup (2012)). Higher capital costs make (real) investment in firms less profitable and lead to reduced economic activity. This goes to show that tightening of effective TC rules will have a negative effect on investment by MNCs. Reduced investment exerts an offsetting effect on tax revenue, i.e., increases in tax revenues calculated for fixed investment will overstate the effective increase in revenue. An advantage of such a regulation-induced increase in capital costs for MNCs might be, however, that the playing field in the national market is levelled as domestic firms cannot employ international debt shifting strategies and as a result face higher effective capital costs than MNCs. However, any real-investment effects of TC rules will not occur if multinationals succeed in structuring around such rules. Hence, the absence of real effects can be an indirect indicator for the (non-)effectiveness of TC rules in empirical studies.

\subsubsection{Tax Competition}

Being exposed to tax competition, governments would like to set a high tax rate for immobile capital (i.e., on domestic firms) and a low tax rate for mobile capital (i.e., on MNCs) in order to attract the latter. If attracting mobile capital cannot be achieved by differentiated tax rates, TC rules become another instrument for tax competition. 
Weak TC rules (or none at all) allow MNCs to avoid national corporate income taxes through international debt shifting. This implies that weak TC rules trigger a (very) low effective tax rate on mobile capital, while the statutory tax rate, being the effective tax rate for immobile capital, may still be relatively high. By combining high statutory corporate tax rates with weak TC rules, a country can therefore impose a high tax burden on immobile capital and still remain attractive for mobile capital (e.g., investment by MNCs); see Haufler and Runkel (2012). The authors show that smaller countries will be more eager in tax competition (i.e., have both lower tax rates and weaker TC rules), as their capital tax base is more elastic. Haufler and Runkel continue by showing that a coordinated tightening of TC rules in all countries will intensify competition in tax rates, but will still increase welfare for all countries. ${ }^{13}$ The reason is that TC rules are the more aggressive instrument and primarily drive tax competition. From reading between the lines of this article, it can also be conjectured that more tax rate harmonization, as intended by the EU Commission, will foster tax competition in TC rules.

To summarize, it is rational to allow for at least some leeway or to impose even very weak TC rules in order to attract mobile capital and to outperform tax competitors. This holds true particularly for small countries. While a coordinated tightening of TC rules increases welfare, an isolated attempt to restrict international debt shifting by means of tighter TC rules reduces real investment not only due to higher effective capital costs, but also because such uncoordinated tightening adversely affects the country's position in the tax-competition game.

\section{Design of Thin-Capitalization Rules: The Case of Germany}

The most drastic change in TC rules can be observed in Germany; at the same time, the rich German data allows for testing of various theoretical aspects of TC rules. Therefore, this section will deal in detail with the German case. Germany introduced its first TC rules in 1994, but had to adjust the rules to EU law in 2004. At first, the TC rules were

13 This holds for symmetric countries at least. If countries are asymmetric, for instance, differ in population size, the effect on welfare becomes ambiguous. This is due to the fact that small countries have strong incentives for tax competition and after harmonization they will excessively use their tax rate as an instrument. Since this is an expensive instrument, welfare in small countries may decrease, depending on parameter constellations. targeting only internal debt in MNCs. ${ }^{14}$ A large tax reform fundamentally changed the system in 2008. After that reform, also the use of external debt may fall under the regulation of thin capitalization.

\subsection{Introduction of Thin-Capitalization Rules: 1994 to 2003}

The first TC rules, implemented in Germany, were targeting internal debt only and - in principle - only applied to corporations. Moreover, the rules applied exclusively to foreign investors (i.e., to German inbound FDI). Financing by internal debt from shareholders or related companies residing in Germany was not affected by these rules. ${ }^{15}$

Germany followed the approach of fixing a debt-toasset ratio serving as a safe harbor. Excessive internal debt was taxed under corporate tax in the same way as equity. In principle, interest expenses on internal debt from foreign investors were not tax deductible if the following two conditions were fulfilled simultaneously: (i) the investor held (directly or indirectly) at least $25 \%$ of the shares of the German affiliate and (ii) the internal debt-to-equity ratio exceeded 3:1 (from 2001: 1.5:1). Thus, internal debt was tax favored as long as its value remained below $300 \%$ of book equity (from 2001: 150\%).

There was an escape clause stating that TC rules would not be applied if it could be successfully proven in an arm's length comparison that the internal debt could have been replaced by external debt from unrelated third parties under the same conditions. The most important loophole indeed constituted the preference given to holding companies. The safe harbor for holdings was defined as 9:1 (from 2001: 3:1) so that German holding companies could be loaded with tax-deductible internal debt by up to $900 \%$ of book equity (from 2001: 300\%). To qualify for the holding regime, an affiliate had to either restrict itself to providing financial services to other related affiliates or the value of total ownership shares held in other affiliates must be at least $75 \%$ of total assets of the affiliate in question.

The TC rules were imposed in 1994 for two reasons: Firstly, they should contribute to the financing of a cut in the statutory corporate tax rate by 6 percentage points, enacted in 1994. The tax authorities expected an annual

14 For a brief history of German TC rules up until 2007, see also Weichenrieder and Windischbauer (2008, section 2).

15 See §8a Körperschaftsteuergesetz in the version of 1994 (2001). There were minor changes enacted in 2001; these only affected the safe-harbor ratio, and new values referring to 2001 are given in brackets. 
increase in corporate tax revenue of 700m DM (approximately 360m EUR) from 1994 onwards due to the introduction of the rules (see Bundesrat Drucksache 1/93, dated 4.1.1993). ${ }^{16}$ Secondly, in 1992, the German supreme tax court had overruled the hitherto existing practice of the tax authorities to disallow extensive thin capitalization based on the general anti-abuse rule.

The rules were tightened in 2001 in order to finance the introduction of the shareholder relief system in Germany and an accompanying further decrease in the corporate tax rate. As a result of this tightening, the tax authorities expected an annual increase in corporate tax revenue of 990m DM (approximately 510m EUR) from 2001 onwards (see Bundesrat Drucksache 90/00, dated 14.2.2000). ${ }^{17}$

\subsection{Adjustment to EU Law: 2004 to 2007}

In reaction to the ECJ ruling in the "Lankhorst-Hohorst case" in December 2002 (see subsection 2.1), Germany started to apply TC rules both to resident and non-resident companies in 2004. Due to this adjustment, the tax authorities expected an annual increase in corporate tax revenue of 1.165 billion EUR from 2004 onwards (see Bundesrat Drucksache 560/03, dated 15.8.2003). ${ }^{18}$

Germany not only started to handle domestic and foreign investors symmetrically, but also used the enforced reform to close some of the loopholes. The preference for holdings was abolished and the debt-to-equity ratio of 1.5:1 applied from 2004 onwards as a safe harbor for all affiliates (including holding companies).

The escape clause via a successful arm's length comparison was preserved. Furthermore, a preference was introduced for small companies in order not to burden them with too high taxes: TC rules did not apply if the interest expenses on internal debt were lower than 250,000 EUR per year.

\subsection{Switch to an Earnings Stripping Approach: from 2008}

In the process of a big reform of both the income and the corporate tax in 2008/2009, Germany implemented a fundamental system change in its thin-capitalization regulation and replaced its traditional rules with an earningsstripping rule (similar to the US approach), called the "Zinsschranke". The motivation for this change was deliberately to increase the (low) ratio of equity in the financing of German companies and limit international debt shifting. Reading between the lines, this indicates that the German tax authorities had been worried about the use of external debt as well, and that this worry was one reason for expanding the scope of German TC rules. From 2008 onwards, the German tax authorities expected annual tax revenues to rise by 1.5 billion EUR, ${ }^{19}$ due to the introduction of the new rule (see Bundestag Drucksache 16/4841, dated 27.3.2007). ${ }^{20}$

The new rule applies irrespective of the legal form of the company and further restricts the extensive use of external as well as internal debt. In fact, Germany ceased to define a safe-harbor ratio and stopped denying the tax deductibility of excessive internal debt, but introduced a limit to the tax deductibility of total debt (see §4h Einkommensteuergesetz, §8a Körperschaftsteuergesetz). Net interest expenses (regardless of whether paid on external or on internal debt) are not deductible from the company's corporate/income tax base, if they exceed $30 \%$ of the company's EBITDA. Any amount of net interest expenses above that threshold does not reduce the tax base. Net interest expenses are defined as the difference between interest paid on debt minus interest income received on debt claims. EBITDA is calculated as taxable profits (before the application of the "Zinsschranke") plus net interest expenses, plus depreciation. However, interest expenses that cannot be deducted from the tax base can be deducted in the following years if, during these years, the threshold of $30 \%$ of EBITDA is not reached. Consequently, this might be called "interest carry forward". Similarly, unused interestdeduction possibilities (i.e., the difference between actual interest expenses and 30\% of EBITDA) can be transferred to and used in the following 5 years.

19 This estimate is based on the original tax threshold of $1 \mathrm{~m}$ Euro in 2008. The threshold was increased to three million EUR in 2009 (see text below). This increase should result in a significant reduction in the expected tax revenue increase. The tax authorities did not present a new estimate after this change.

20 For comparison, the actual corporate tax revenue in 2008 was 16 billion EUR; see Statistisches Bundesamt (2011).
16 For comparison, the actual corporate tax revenue in 1994 was 10 billion EUR; see Statistisches Bundesamt (2011).

17 For comparison, the actual corporate tax revenue in 2001 was negative (-426m EUR) due to adjustment effects of the introduction of the shareholder relief system. See Statistisches Bundesamt (2011).

18 For comparison, the actual corporate tax revenue in 2004 was 13 billion EUR; see Statistisches Bundesamt (2011). 
There are various exceptions to the applicability of the new German TC rules. Collectively, these exceptions should ensure that purely domestic firms, and particularly small and medium-sized enterprises, are not affected by the rule. To serve small and medium-sized enterprises directly, a tax threshold of EUR 3m (EUR 1m in 2008) was introduced. As long as total net interest expenses are below this threshold, the "Zinsschranke" does not apply, even if the net expenses exceed 30\% of EBITDA. Note, however, that this threshold is not a tax allowance: as soon as the threshold is exceeded by 1 euro, tax deductibility is denied for the full amount of net interest expenses exceeding 30\% of EBITDA.

TC rules do not apply also if the company is not part of a consolidated group ('group clause'). A company is part of a consolidated group if it can be consolidated with other companies following IFRS or, in exceptional cases, following US-GAAP or German GAAP. A company is also considered as part of a consolidated group if its business policy is jointly determined with other companies. Finally, the so-called "escape clause" was introduced: the earningsstripping rules are not applied if the German company can prove that its debt-to-asset ratio is equal to or less than the average debt-to-asset ratio of the group to which the company belongs. Thereby, exceeding this group-wide debt-toasset ratio by no more than 2 percentage points is harmless. Given that within one country the differences in incentives for relying on debt financing should be negligible for affiliates of one and the same group, the escape clause should ascertain that groups having all their affiliates in Germany will not face TC rules. The same holds for groups having a high debt-to-equity ratio in general, but not extensively shifting debt to Germany.

The group clause does not apply to companies organized in the legal form of corporations if a shareholder holds (directly or indirectly) at least $25 \%$ of the shares of the German corporation in question and the interest paid on internal debt received from this shareholder exceeds $10 \%$ of the corporation's net interest expense. Nor does the escape clause apply in such cases if the interest bearing internal debt is shown in the group's consolidated financial statement.

\section{Empirical Evidence}

\subsection{International Debt Shifting}

There is a common belief that international debt shifting is used by MNCs for the purpose of decreasing their tax load in high-tax countries. The assumed tax planning strategies are twofold: firstly, MNCs are assumed to finance affiliates in high-tax countries using internal debt instead of equity, which would result in a higher internal debt-to-asset ratio in high-tax countries. Secondly, MNCs are assumed to locate third-party debt in affiliates in high-tax countries. Therefore, higher corporate tax rates should go along with higher external debt-to-asset ratios. These two predictions should also result in an increased total debt-to-asset ratio as the most general measure.

The empirical evidence for this common belief is rather weak. Empirical papers studying the effect of corporate taxation on the debt-to-asset ratio find only a modest increase of the debt-to-asset ratio. One of the most prominent studies in this field is Desai et al. (2004) investigating the worldwide difference in affiliates' debt-to-asset ratios for US-MNCs. They find a $2.8 \%$ increase in an affiliate's debt-to-asset ratio following a $10 \%$ increase in the corporate tax rate. ${ }^{21}$ The predicted increase in the internal debt-to-asset ratio (3.5\%) following a 10\% increase in the corporate tax rate is more pronounced than the predicted increase in the external debt-to-asset ratio (1.9\%). Many other empirical studies come to similar conclusions (e.g., Huizinga et al. (2008); Møen et al. (2011)).

These results are in sharp contrast to anecdotal evidence provided by tax consultants and tax auditors. We believe that this apparent contradiction is driven by the fact that empirical studies typically take into account all available MNCs, including many small MNCs, for example, medium-sized firms opening sales affiliates abroad. Most such MNCs do not engage in international debt shifting. As a result, empirical studies find rather modest effects on average, as summarized above. On the contrary, tax consultants and tax auditors typically have in mind a few large MNCs that engage in aggressive tax planning.

\subsection{Empirical Evidence on International Thin-Capitalization Rules}

With respect to the US earnings stripping rule, Knipe et al. (2009, p. 101ff) refer to a study by the US Department of the Treasury, which in 2007 concluded that due to lack of data it cannot be determined whether the US rule is ef-

21 The mean debt-to-asset ratio in the study is $55.2 \%$ and the mean corporate tax rate is $34.3 \%$. Using these sample means as the benchmark, their results imply an increase in the debt-to-asset ratio from $55.2 \%$ to $56.7 \%$ if the corporate tax rate increases by $10 \%$ from $34.3 \%$ to $37.3 \%$ as an example. 
fective. ${ }^{22}$ Indeed, to the best of our knowledge, Blouin et al. (2014); Büttner et al. $(2012,2014)$ are the only studies available that investigate TC rules worldwide. In both papers, Büttner et al. use the MiDi database on German MNCs and their foreign affiliates, which is provided by Deutsche Bundesbank..23 Büttner et al. (2012) find TC rules to be effective in reducing the incentive to use internal loans for tax planning but at the same time to lead to higher external debt. The economic size of the identified effect depends on a country's corporate tax rate as well as on the specific TC rule imposed. As an example, they evaluate the implications of imposing a thin-capitalization rule in a host country with a tax rate equal to the sample average of 34\%. Implementing a TC rule with a safe haven debt-toequity ratio of 2:1 results in a drop of the internal debt-toasset ratio by 3.2 percentage points (e.g., from $60 \%$ down to $56.8 \%$ ). If the host country instead defines the safe haven in terms of total debt, the predicted decline in the internal debt-to-asset ratio amounts to as much as 6.6 percentage points. Büttner et al. (2014) investigate investment effects of TC rules. Their results indicate that, compared to the unrestricted case, the tax-rate sensitivity of FDI is about twice as large in the presence of a typical TC rule. In accordance with predictions from economic theory, see subsection 2.2.2, this finding implies that TC rules are effective indeed.

Blouin et al. (2014) examined the impact of TC rules on the capital structure of foreign affiliates of US multinationals using BEA data. They find that TC rules affect multinational firms' capital structures in a significant way. Specifically, restrictions on an affiliate's total debt-to-asset ratio reduce this ratio on average by $1.9 \%$, while restrictions on an affiliate's borrowing from the parent, that is the parentto-equity ratio, reduce this ratio by $6.3 \%$. Another important finding in that study is that the stronger the effect of TC rules is the more automatic their application is enforced and the less discretion is available.

22 There is, however, some research on the "interest-allocation rule" for US MNCs with foreign income. Under some conditions, this rule partially denies interest deductibility in the parent company, similarly to a TC rule. In such cases, there will be a negative effect on the use of debt. See Froot and Hines (1995); Altshuler and Mintz (1995).

23 However, Büttner et al. (2012) do not consider German affiliates of German MNCs. This limitation is due to their dataset not containing these affiliates. Thus, the study analyzes the effects of all TC rules worldwide except for the German ones.

\subsection{Empirical Evidence from Germany}

\subsubsection{Empirical Evidence on German Thin-Capitalization Rules before 2008}

Three empirical studies investigate the effect on MNC policy of the German TC rules in place before 2008: Overesch and Wamser (2010); Wamser (2014); Weichenrieder and Windischbauer (2008). Like Büttner et al. (2012); all these studies exploit the MiDi database, but they focus on inbound investment, that is, on German affiliates of foreign MNCs. According to the results of Weichenrieder and Windischbauer (2008), German TC rules were successful in reducing thin capitalization of foreign MNCs' affiliates residing in Germany, while they did not affect their real investment. The authors further provide evidence for MNCs working around the German TC rules using a loophole in the legislation created by the preference given to holding companies. The use of this loophole could provide an explanation for Weichenrieder and Windischbauer (2008) finding no effects on real investment. If MNCs used the loophole and shifted internal debt from affiliates to holdings, we observe a decreasing affiliate debt-to-asset ratio. At the same time, MNCs had no need to adjust their investment policy, because, due to the use of the loophole, their cost of capital did not change.

Overesch and Wamser (2010) find that the internal debt-to-asset ratio decreased by 2.5 percentage points on average due to the tightening of the German TC rules in 2001. For holding companies the decrease was 10 percentage points and thus more pronounced. ${ }^{24}$

Wamser (2014) considers the impact of the tightening of German TC rules in 2001 on the internal and external debt-to-asset ratio of German affiliates of non-German MNCs. Affected affiliates decreased their internal debt-toasset ratio by 5 percentage points. At the same time, however, affected affiliates increased their external debt-toasset ratio (not affected by TC rules at this time) by 2.7 percentage points. Hence, roughly half of the effect on the internal debt-to-asset ratio was neutralized through an opposite effect on the external debt-to-asset ratio.

Neither Overesch and Wamser (2010), nor Wamser (2014) consider investment effects. Table 1 provides an overview of the core results of the empirical studies cited here.

24 Overesch and Wamser (2014) restrict on a subsample for which they can identify bilateral internal debt and come up with precise bilateral tax-rate differentials. With respect to effects of thincapitalization rules, their findings support the results in Büttner et al. (2012); Overesch and Wamser (2010). 


\subsubsection{Empirical Evidence on the German Thin-Capitalization Rules after 2008}

Two econometric working papers analyse the rules that came into force after the substantial change in the German TC rules in 2008. Buslei and Simmler (2012) estimate that firms threatened to be affected by the new German 2008 TC rules have reduced their debt-to-asset ratio by 5.3 percentage points. Given the mean debt-to-asset ratio in their sample of $65 \%$, this is an $8 \%$ reduction. They find no effect on investment caused by the new German 2008 TC rules. According to the results of Dreßler and Scheuering (2012), firms lowered their debt-to-asset ratio and their net interest payments due to the introduction of the new rules. Opposing the original intention of the reform in Germany, the authors also find (purely) domestic firms to adjust their capital structure. In general, firms reduced external rather than internal debt.

Further, there are two rather descriptive analyses of the new rules. Based on publicly available financial statements of German firms, Blaufus and Lorenz (2008) conclude that only between 500 and 1500 out of all existing German corporations should be affected by the new rules. Herzig et al. (2008) sent out 239 questionnaires to listed and/or large German corporate groups. $55.7 \%$ of the 70 answering companies claimed to be affected by the new rules a priori. $90 \%$ of the affected firms, however, confirmed that they were planning to take measures in order to avoid being hit by the new rules.

Bach and Buslei (2009); Bach (2009); Broer (2009) provide empirical evidence based on microsimulation models. Based on publicly available financial statements for the financial year 2006, Bach and Buslei (2009) estimate the introduction of the new rules to raise tax revenue by $750 \mathrm{~m}$ EUR.Bach (2009), using the same microsimulation model as Bach and Buslei (2009), finds the change of the tax threshold from EUR 1 to $3 \mathrm{~m}$ in 2009 to reduce the expected tax-revenue effect of EUR $750 \mathrm{~m}$ by $7 \%$. However, as a limitation, these studies do not take into account behavioral responses of firms and consider publicly available financial statements only. Using the German trade tax statistic for his microsimulation, Broer (2009) estimates the increase in the tax revenue to be within a band of EUR 809 to $2537 \mathrm{~m}$ due to the introduction of the new rules in 2008 .

\section{The Nordic Countries: Following the German Example}

While Germany has an experience with TC rules for more than 20 years now, most Nordic countries did not have any TC rules until recently and Iceland still goes without them. The exception is Denmark that started in 1999 already. When introducing their TC rules, Denmark, Finland and Norway used the German example as a blueprint, adopting it to their needs. Only Sweden took a very different approach. ${ }^{25}$

In 1999, Denmark introduced safe-harbor type TC rules with a safe harbor for total debt to equity of 4:1. Thus, as long as a firm's total debt-to-asset ratio does not exceed $80 \%$, all interest expenses are tax deductible. If the total debt-to-asset ratio of the firm is higher than $80 \%$, tax deductibility is denied on that part of internal debt that needs to be converted into equity in order to achieve the minimum requirement of $20 \%$ of 'equity' (i.e., equity plus nondeductible internal debt). As long as the amount of internal debt is below DKK 10m ( $\approx$ EUR 1.3m), the safe-harbor rule will not be applied, however.

In addition to the traditional safe-harbor rule, an earnings stripping rule was put in place from 2008. Like the new German rule, it limits deductibility of net interest expenses on total debt (i.e., also on external debt), but there are major differences. Denmark bases its threshold not on EBITDA, but on the larger measure EBIT ("earnings before interest and taxes") and denies tax deductibility for any net interest expense exceeding $80 \%$ of EBIT. There are no escape or group clauses so that also purely domestic firms are limited in their deductibility of interest expenses on external debt. But, analogous to Germany, only firms with net interest expenses above DKK 21.3m ( $\approx$ EUR $2.9 \mathrm{~m}$ ) fall under the earnings stripping regulation. Furthermore, an interest-ceiling rule is in place since 2008 , constituting a third pillar for restricting excessive thin capitalization. ${ }^{26}$ Leading to some kind of "asset test", the interest-ceiling rule limits the deduction of net financial expenses to $4.2 \%$ (2014 rate) of the taxable value of certain qualified assets. ${ }^{27}$

In total, Denmark is combining the old and the new German approaches (but with quite some differences with

25 Folkvord and Jacobsen (2014, section 4.2), provide a brief overview on the recent development in all anti-avoidance rules in the Nordic countries.

26 Note that all three pillars are active at the same time.

27 See, for example, Ernst \& Young (2014, pp. 351), and Det Kongelige Finansdepartementet (2013), section 4.4.2, for an overview on the Danish regulation. 
respect to the earnings stripping regulation) and extending it by adding an interest-ceiling rule.

Sweden implemented a "targeted limitation" in 2009 that banned tax deductibility of internal interest expenses when financing mergers \& acquisitions, and expanded this ban to all kinds of interest payments on internal debt in 2013, turning it into a real thin-capitalization regulation. ${ }^{28}$ This rule can be waived if either the internal lender has to pay at least $10 \%$ of tax on its interest income received or if the internal loan is driven by business reasons and not granted for tax purposes only. The $10 \%$ tax-rate clause requires that the lender would have to pay at least $10 \%$ taxes if the received interest income would be its only income, and that the transaction is not tax motivated. The business reason clause also requires that the internal debt is not only used for tax avoidance, but has some justification in the conducted business. When applying for the business reason clause, the internal lender must be located in an EEA country or a country with an appropriate tax treaty with Sweden.

Obviously, there is some analogy to CFC rules implementing a threshold tax rate on interest income in the internal bank and coming with an activity clause (see subsection 6.2 below). In a thorough examination, a Swedish government committee evaluated the Swedish "targeted limitation" as ineffective and undesirable. The new proposal is to replace the existing regulation by a so-called "CBIT" (see subsection 6.3 below) that denies all (net) interest deductions, see SOU2014:40 (2014); Lodin (2014).

In 2012, Finland decided to follow the German example and put its regulation of thin capitalization effective from January 2014. ${ }^{29}$ For taxpayers doing business activities under the Business Income Tax Act (BITA), it adopts the German earnings stripping rule (including the "interest carry forward" and the "escape clause"), except for two important differences. ${ }^{30}$ First, only net interest expenses on related-party (i.e., internal) debt can be denied tax deductibility; second, the threshold with respect to EBITDA is $25 \%$ instead of $30 \% .^{31}$

28 See, e.g., Pentillä and Nieminen (2014), p. 239, and Det Kongelige Finansdepartmentet (2013a, section 4.4.3).

29 See Penttilä and Nieminen (2013), in particular sections 5 to 9, for a detailed overview and some background.

30 Minor differences are the lower tax threshold of EUR 500,000 and a $50 \%$ instead of $25 \%$ limit for capital shares or voting rights when evaluating related parties. The "group clause" is also absent - and is unnecessary since external debt is not restricted.

31 Originally, it was planned to use the same threshold as in Germany, but in a last-minute change, it was reduced to $25 \%$ of EBITDA.
Taken together, this regulation implies that a nondeductibility test will be applied whenever the net interest expenses on total debt exceed EUR 500,000. Then, net interest expenses on internal debt are tax deductible only until the total net interest expenses reach $25 \%$ of EBITDA. Hence, as soon as external debt causes net interest payments of 25\% of EBITDA (or more), net interest payments on internal debt can no longer be deducted from the tax base in the current tax year.

Norway was the Nordic country that followed the German rules the closest when enacting its rules from January 2014. ${ }^{32}$ Actually, there is only one major, but important difference. Likewise Finland, Norway does not limit the deductibility of interest expenses on external debt. Still, interest expenses on external debt crowd out the deductibility of (net) internal interest expenses. Using the German $30 \%$ of EBITDA (or more precisely, a "tax-law equivalent measure" of EBITDA) as a threshold, this implies that net interest expenses on internal debt are no longer tax deductible as soon as the expenses on external debt reach the threshold. Due to the fact that expenses on external debt are not limited even if they exceed $30 \%$ of EBITDA, there is no need to protect small and purely domestic firms. Hence, Norway did not introduce exceptions such as the "escape clause" or the "group clause". A minor difference is that the tax threshold amounts to NOK 5m ( $\approx$ EUR 600,000) only.

In December 2014, a government committee (the socalled Scheel committee) recommended to tighten the Norwegian rules by restricting deductibility of interest expenses on external debt as well. The proposal goes beyond the German rules, because it does not provide any escape clause for purely domestic companies and, by intending to limit deductable interest expenses to $45 \%$ of EBIT (i.e., earnings before interest and taxes), it is more inspired by the Danish regulation, actually. See (NOU2014:13, 2014, section 1.4.4.4 and chapter 8).

Putting everything together, the Nordic countries, except for Sweden and Iceland, implemented TC rules for which Germany has quite some experience. Based on the empirical results on Germany, see section 4.3, we conjecture that the Nordic versions of these rules are effective as well and, in particular, that the "newcomers" Finland and Norway should be able to achieve their intended effects with their new regulation.

See the Finish Ministry of Finance's press release from November 13, 2013. We are grateful to Seppo Kari for bringing this to our attention. 32 Cf Det Kongelige Finansdepartmentet (2013a, section 4), as well as Det Kongelige Finansdepartmentet (2013b, section 6.1), for some minor changes in the final law. 


\section{Comparison with Potential Alternative Regulation}

As we have seen, effective TC rules can have substantially negative effects on domestic investment. Furthermore, they might be hard to rationalize in a tax competition setting, particularly for small countries. Therefore, we will briefly characterize the arm's length principle and CFC rules as potential alternatives within the traditional system of corporate income taxation. Moreover, we will briefly discuss the effects of a fundamental tax reform towards either a system with an ACE or a CBIT. Further alternatives under discussion (cf. de Mooij (2011, section VI.A)) are introducing a cap on the interest rate for which deductions are granted and abolishing interest deductibility of intracompany loans. The "cap method" is very similar to the arm's length principle, and denying tax deductibility for internal debt effectively corresponds to the German "Zinsschranke" when the safe haven of 30\% of EBIDTA is decreased to zero. Therefore, we are not going to analyze these two alternatives separately.

\subsection{Arm's Length Principle in Debt Shifting}

One alternative to introducing safe-harbor rules or earnings-stripping rules is to rely exclusively on the arm'slength principle as done in Norway before 2014 and still in the U.K.

In general, the arm's length principle implies a caseby-case assessment of (i) whether the interest rate paid on internal debt corresponds to the interest rate that would have to be paid to an unrelated third party; (ii) whether the loan could have been obtained from unrelated third parties under the same terms; and potentially (iii) whether the debt-to-equity ratio would have been chosen, if only external debt financing had been available.

As market interest rates for comparable risk classes are observable in principle, it should be possible to test the first issue. Nevertheless, there can be severe problems in establishing a comparable situation. Assessing the the other two criteria is even harder, because the necessary information is even less available. Under perfect information, the arm's length principle would be optimal, since it ensures justice for each individual case. In an imperfect world with limited and asymmetric information, however, the administration costs will be (excessively) high - both for firms having to prove that their financial structure is at arm's length and for tax authorities assessing the firms' argumentation. The arm's length principle might in fact even be counter-productive: as long as a firm can claim that its investment is profitable given its financial structure, and that it would be more expensive to raise new equity (e.g., due to market conditions), the arm's length principle could be used to claim even higher interest rates on internal debt, since for such an "excessive debt-to-asset ratio" a corresponding loan would have been granted by external lenders only at correspondingly high interest rates. Having this in mind, a fact that at first sight might seem surprising may be consistently explained: the British tax authority accepts the debt-shifting strategy of the Formula One business, in which several highly internal-debt loaded firms under the umbrella of the British Delta Topco Holding are paying $15 \%$ interest to an internal bank located on the Channel Island Jersey, which is well known as a tax haven. See Sylt and Reid (2011).

In sum, the economic effects of an effective arm's length principle (i.e., its advantages and disadvantages) are analogous to the effects of the safe-harbor rule that was in place in Germany until 2007. For tax authorities, information is limited, however, and the administrative costs of the arm's-length principle would be enormous. Consequently, we do not consider the arm's-length principle as a proper alternative to $\mathrm{TC}$ rules.

\subsection{Controlled-Foreign-Company Rules}

A potential alternative, by which most of the unintended effects of TC rules are avoided, but similar results are achieved, are CFC rules. However, CFC rules come at other costs.

\subsubsection{The United States and Germany}

The US introduced so-called "Subpart F" rules in 1964. Germany followed these rules closely, when implementing its CFC rules in 1972 (see $\$ \S 7$ to 14 of the so-called "Hinzurechnungsbesteuerung" in the German Außensteuergesetz). ${ }^{33}$ For so-called "passive income", earned in affiliates of German MNCs, German CFC rules prevent the application of the tax-exemption principle and lead to the passive income immediately being included in the corporate tax base of the MNC's headquarters, if (i) this income stems from non-productive activities (e.g., interest income in affiliates without a banking license, earned on capital not

33 A detailed description and some legal interpretations may be found in Förster and Schmidtmann (2004). 
raised from unrelated third parties), (ii) the MNC (directly or indirectly) holds at least $50 \%$ of the voting rights in the affiliate under consideration, and (iii) the affiliate faces a tax rate below $25 \%$. Thus, if CFC rules are applicable, passive (interest) income will be taxed at the German corporate tax rate regardless of in which country the income is effectively accrued. Ruf and Weichenrieder (2012) provide strong empirical evidence that the German CFC rules are effective.

\subsubsection{The Nordic Countries}

All Nordic countries have CFC rules following the US and German example. ${ }^{34}$ A Danish company is liable to tax on the income of a Danish or foreign subsidiary if the subsidiary is controlled directly or indirectly by the Danish resident company, the tainted income of the subsidiary amounts to more than $50 \%$ of the total taxable income and the financial assets of the subsidiary exceed 10 per cent of the total assets.

The Swedish CFC rules stipulate that, in certain cases, the foreign entity is treated as transparent for tax purposes in cases of direct or indirect holdings of at least $25 \%$ of low-taxed foreign companies. A foreign company is considered as low-taxed if the foreign tax is less than $55 \%$ of the tax that would have been imposed if the foreign entity had been a Swedish limited liability company. A general exemption from Swedish CFC taxation applies to companies in countries on a special white list. As a main rule, the CFC legislation applies to all income. However, income from genuine economic activities within the EEA may be excluded.

Iceland introduced CFC rules in 2009. The Icelandic CFC rules are designed to prevent tax evasion by targeting companies that primarily have financial earnings, such as holding companies and funds. If the CFC rules apply, the Iceland entity is subject to tax on the income of the CFC. The rules apply only to companies resident in low-tax jurisdictions defined as a country where the general income tax rate on corporate profits is less than two thirds of the Icelandic rate.

In Norway, CFC rules apply if a company is considered to be Norwegian controlled ( $50 \%$ of the company being directly or indirectly owned by Norwegian taxpayers) and is resident in a low-tax jurisdiction. A country is considered to be a low-tax country if the effective tax rate on the in-

34 The following details on the rules are extracted from Deloitte (2014); Ernst \& Young (2014); Folkvord and Jacobsen (2014). come in question is lower than $2 / 3$ of the equivalent Norwegian company tax. The Norwegian CFC rules are not applicable if the CFC company is engaged in genuine business in the low-tax country or if the country is on the Norwegian white list of low-tax countries.

Under the Finish CFC rules, the foreign entity must be subject to a tax that is lower than $3 / 5$ of the corresponding Finnish tax. Since the Finnish corporate tax is currently $20 \%$, the foreign entity's tax rate should be below $12 \%$. Further, the Finnish shareholder must hold, directly or indirectly, at least $25 \%$ of the capital of the foreign entity. The CFC rules do not apply to income derived from industrial production or similar production activity, shipping and sales or marketing activity regarding the first two categories of activities.

\subsubsection{Economic effects}

For affiliates that serve as an internal bank (i.e., that provide internal debt) and face binding CFC rules, the taxexemption principle (i.e., the source principle) no longer applies. They are taxed according to the credit method so that the relevant tax rate on interest income received is the tax rate of the headquarters of the MNC. Hence, for all affiliates having a lower tax rate than that of the headquarters, the internal debt tax shield turns negative since their tax savings from borrowing internal debt are now lower than the induced tax payments on shifted interest income in the internal bank.

Consequently, binding CFC rules imply that internal debt-to-asset ratios fall to zero in domestic affiliates of a domestic MNC as well as in all affiliates facing a lower tax rate than the headquarters. For affiliates facing a higher tax rate, internal debt shifting still remains profitable, but to a lesser extent as their internal debt tax shield has decreased. Ceteris paribus, tightening of effective CFC rules in country $A$ increases financing by equity and tax revenue for all countries with affiliates of MNCs headquartered in country $A$. Furthermore, if the CFC rules specify the tax rate of country $A$ as the relevant threshold, there is a strong incentive for the MNCs to locate their internal banks at their headquarters - leading to another increase of tax revenue in country $A .{ }^{35}$

35 Amazingly, Germany did never exploit this fact. The threshold for the tax rate was $30 \%$ before and is reduced to $25 \%$ since 2001 , whereas the effective German corporate tax rate (including the local "Gewerbesteuer") was close to $39 \%$ before 2008 and has been approximately 29\% since the latest reform in 2008. 
Compared to TC rules, binding CFC rules can perfectly prevent thin capitalization by internal debt shifting for domestic affiliates of domestic MNCs, but do not affect domestic affiliates of foreign MNCs. Hence, CFC rules should be compatible with tax competition, since they do not burden mobile foreign capital, but make mobile domestic capital less mobile. The direct gain in tax revenue will be less than with TC rules, but this might be compensated if the domestic MNCs relocate their internal banks to their headquarters.

While CFC rules do not trigger negative investment effects for foreign MNCs and can be sustained in a tax competition setting, they induce some other costs. For domestic MNCs, the effective capital costs will increase and, as a consequence, these MNCs will reduce their domestic investment. Moreover, all foreign affiliates of domestic MNCs will also experience an increase in their effective capital costs. This triggers a worldwide reduction in real investment of domestic MNCs and this effect can be very substantial (cf., Egger and Wamser (2011)). Hence, CFC rules challenge the competitiveness of domestic MNCs relative to foreign MNCs. Furthermore, CFC rules lower a country's attractiveness as a location for MNC headquarters.

Another obstacle to implementing CFC rules may be EU law. In the so-called "Cadbury-Schweppes case", the ECJ ruled in 2006 that the British CFC rules violated the "freedom of establishment" and must not be applied (to European MNCs). ${ }^{36}$ Cadbury-Schweppes wanted to utilize preferential tax regimes in Ireland to substantially reduce its tax burden in the UK, and the British tax authority tried to prevent this. However, the ECJ determined that seeking a tax advantage is not sufficient to restrict the principle of the freedom of establishment. The only endurable exception would be cases of "purely artificial structures" (e.g., pure letterbox companies). As a reaction, all EEA countries apply their CFC rules to affiliates residing in other EEA countries only if these affiliates constitute such purely artificial structures.

An issue that has not yet been tested and which might challenge the sustainability of CFC rules even more, is the question of whether CFC rules violate the "freedom of movement of capital". Förster and Schmidtmann (2004, section 6 C) provide a short summary of critical issues.

\subsection{Changing the Corporate Tax System: ACE and CBIT}

The tax advantage given to debt over equity in traditional corporate income tax systems (i.e., treating interest payments on debt as business expenses, but denying deductibility of the costs of equity from the tax base) can hardly be justified on economic grounds. ${ }^{37}$ Therefore, an alternative to fixing (or trying to fix) resulting problems related to this tax advantage (e.g., excessive risk taking and debt shifting) by implementing additional regulation (e.g., by TC rules) is to eliminate the tax advantage of debt in the course of a fundamental tax reform. This view has gained ground over the last 20 years and has resulted in a large strand of literature. There are two options: introducing an ACE, as proposed by the Institute for Fiscal Studies (1991) and inspired by Boadway and Bruce (1984), or implementing a CBIT, as recommended by the US Department of Treasury (1992).

A CBIT denies tax deductibility of any financing costs so that both the return on equity and the interest on debt are taxed at firm level at the corporate tax rate. As a result, the marginal capital investment is distorted more heavily than under the traditional system of interest deductibility. An ACE system, on the contrary, amends interest deductibility of debt with a notional deduction for equity employed equivalent to the "risk-free" rate of return. This procedure leaves the normal rate of return on capital free of tax at firm level and taxes only economic ("supernormal") profits.

As, all else equal, the ACE has several attractive neutrality features (e.g., not distorting marginal investment), it is preferred by many economists, particularly in Europe, and recommended by the Mirrlees Report (Mirrlees et al. (2011, chs. 17 and 18)). The picture becomes unclear, however, when tax revenue effects and capital mobility are taken into account. For a balanced budget reform, introducing an ACE requires an increase either of the corporate tax rate or of other taxes, because an ACE reduces the corporate tax base. Instead, a CBIT enlarges the corporate tax base and allows for cutting taxes on other accounts. If these adjustments are implemented by changes in the corporate tax rate, a lower effective average tax rate in a CBIT country allows for attracting MNCs, discrete investment and shifted profits. Then, an ACE loses its advantage and a CBIT can even do better on welfare grounds. See De

37 See de Mooij (2011, section IV) for an intuitive summary and evaluation of some reasons that have been put forward for why there should be a tax advantage.
36 The judges argue that denying tax-exemption for low-tax affiliates only would create an imbalance to the treatment of domestic and high-tax affiliates. 
Mooij and Devereux (2011) who provide simulation results for the EU as well as a review of earlier literature.

With respect to thin capitalization, both systems abolish the tax advantage of debt and eliminate the incentive for (international) debt shifting on the corporate level (given that the notional deduction for equity meets the effective interest costs for debt). At least when focusing on corporate taxation only, replacing equity by debt or trying to shift interest income to low-taxed affiliates does not reduce tax payments, and the capital structure of an affiliate under either CBIT or ACE will be independent of taxation. Hence, both tax systems are very attractive alternatives to TC rules.

Contrary to a CBIT system, there is some experience with ACE in the real world. Belgium, for example, introduced an ACE system in 2006 ("Notional Interest Deduction") which for the year 2012 grants a deduction of 3 percentage points from the taxable return to equity (formerly, the deduction rate was equal to the average rate of 10-year government bonds 2 years prior to the tax year under consideration); cf. Federal Public Service (2012). In 2011, Italy introduced an ACE system ("Aiuto alla Crescita Economica"), as well. This also allows for an imputation rate of $3 \%$, which is about half the Italian market interest rate (Panteghini et al. (2012, section 3)). Empirical analyses show that for both Belgium and Italy, the introduction of an ACE system significantly decreased leverage in firms registered in these countries by about 3 to $5 \%$ on median - although in both countries. The allowances are insufficient to fully eliminate the tax preference given to debt; see Princen (2012) and Panteghini et al. (2012), respectively.

On the other hand, the German earnings-stripping rule ("Zinsschranke") could be interpreted as a first step towards a (partial) CBIT. Given all its exceptional rules (e.g., group clause, escape clause), however, the "Zinsschranke" in fact constitutes a restriction on internal debt only, and the rule does not allow us to derive any conclusions about the critical effect of denied interest deductibility on investment.

\section{Conclusions}

This paper summarizes the design of TC rules, particularly some recent developments in Germany, as well as theoretically predicted effects and empirical evidence available. From a theoretical point of view, we expect TC rules to limit international debt shifting and decrease the debt-to-asset ratios of domestic affiliates of multinationals. This comes at the cost of reduced domestic investment, because TC rules increase the domestic cost of capital and adversely affect a country's position when competing internationally for mobile capital. The decrease in debt-to-asset ratios has a positive effect on tax revenue, while the reduced investment has a negative effect. The overall effect is theoretically ambiguous.

Special emphasis is given to Germany, because Germany has a long tradition of TC rules and enacted a fundamental reform towards an earnings stripping approach in 2008. Moreover, available data on German multinationals is outstanding. Empirical studies find the German TC rules to be effective in reducing internal debt-to-asset ratios. Furthermore, such TC rules are more effective if they are automatically applied and do not grant much discretion to tax authorities. But, the empirical results also show that multinationals make use of loopholes (e.g., rely more on preferred holding structures) and increased external debtto-asset ratios. Therefore, it is not too surprising that these studies do not find clear evidence of reduced investment (in Germany). Hence, it remains a somewhat open question how effective (German) TC rules are. Still, balancing all the effects, tightening or introducing TC rules should in general result in increased tax revenue, but come at the risk of reduced investment, particularly in small countries because there the tax-competition aspect is more relevant. Nevertheless, taking all effects into account, one should expect that countries such as Norway and Finland, having adopted German-type earnings-stripping rules in 2014, will achieve their intended effects. On the other hand, it might come as less of a surprise that it is Sweden opting for a CBIT system now. This country tried a very special, non-standard version of thin-capitalization rules, first.

In general, a potential alternative might be to rely on CFC rules. CFC rules also increase tax revenue by restricting international debt shifting, but offer the advantage of not adversely affecting a country's position when competing internationally for mobile capital. The downside is that they would harm the competitiveness of domestic multinationals relative to foreign competitors. ${ }^{38}$ Using the arm's length principle instead of TC rules is in our opinion no attractive option, since this alternative appears to be administratively too costly and impracticable.

In the event of a fundamental tax reform, both CBIT and ACE are attractive options with a view to reducing thin capitalization and eliminating debt shifting. Both systems should decrease firms' leverage and can eliminate the in-

38 We also need to report that Sweden obviously was not pleased with its experience with a CFC-rule-like regulation of thin capitalization. 
centive for debt shifting. For ACE, there is at least some empirical evidence of reduced leverage. Answering the question of whether one of these systems (and if so, which one) should be implemented, needs to take into account many more aspects, however, and is still an issue of open debate (e.g., De Mooij and Devereux (2011)) - which is far beyond the scope of this paper.

Acknowledgement: This paper is based on a report for the Norwegian Tax Authority for which financial and administrative support by this institution is gratefully acknowledged. We are also grateful to the German Ministry of Finance (Bundesministerium der Finanzen), in particular to Michael Sell, as well as to Seppo Kari, Valeria Merlo, Oddleif Torvik, Georg Wamser and two anonymous referees for providing us with very helpful information and suggestions. Furthermore, we benefitted a lot from discussions with Ruud de Mooij and Axel Hilling.

\section{References}

Altshuler R. and Mintz J.M., 1995. U.S. Interest-Allocation Rules: Effects and Policy. International Tax and Public Finance 2, 7-35.

Bach S. and Buslei H., 2009. Empirische Analysen zur Zinsschranke auf Grundlage von Handelsbilanzdaten. DIW Research Notes 30, Berlin.

Bach S., 2009. Stellungnahme des DIW Berlin zum Gesetzentwurf Bürgerentlastungsgesetz Krankenversicherung BT-Drucksache 16/12254 und BR-Drucksache 168/09. DIW Berlin.

Blaufus K. and Lorenz D., 2009. Wem droht die Zinsschranke? Eine empirische Untersuchung zur Identifikation der Einflussfaktoren. Zeitschrift für Betriebswirtschaft 79, 503-526.

Blouin J., Huizinga H., Laeven L. and Nicodeme G., 2014. Thin Capitalization Rules and Multinational Firm Capital Structure. CentER Discussion Paper No. 2014-007.

Boadway R. and Bruce N., 1984. A General Proposition on the Design of a Neutral Business Tax. Journal of Public Economics 11, 93-105.

Broer M., 2009. Ziele, Wirkungsweise und Steueraufkommen der neuen Zinsschranke. Schmollers Jahrbuch 129, 391-413.

Büttner T., Overesch M., Schreiber U. and Wamser G., 2009. Taxation and Capital Structure Choice - Evidence from a Panel of German Multinationals. Economics Letters 105, 309-311.

Büttner T., Overesch M., Schreiber U. and Wamser G., 2012. The Impact of Thin-capitalization Rules on the Capital Structure of Multinational Firms. Journal of Public Economics 96, 930-938.

Büttner T., Overesch M. and Wamser G., 2014. Anti Profit-Shifting Rules and Foreign Direct Investment, CESifo Working Paper No. 4710, Munich.

Buslei H. and Simmler M., 2012. The Impact of Introducing an Interest Barrier - Evidence from the German Corporation Tax Reform 2008. DIW Discussion Papers 1215, Berlin.

Deloitte 2014. Guide to Controlled Foreign Company Regimes. Accessed online at http://www2.deloitte.com/content/dam/ Deloitte/global/Documents/Tax/dttl-tax-guide-to-cfc-regimes-
210214.pdfonNovember13th2014.

De Mooij R.A., 2011. Tax Biases to Debt Finance: Assessing the Problem, Finding Solutions. IMF Staff Discussion Note SDN/11/11, Washington DC.

De Mooij R.A. and Devereux M., 2011. An Applied Analysis of ACE and CBIT Reforms in the EU. International Tax and Public Finance 18, 93-120.

Det Kongelige Finansdepartement, 2013a. Prop. 1 LS (2013-2014): Skatter, Avgifter og Toll 2014. Proposisjon til Stortinget (forslag til lovvedtak og stortingsvedtak) for budsjettåret 2014, Oslo.

Det Kongelige Finansdepartement, 2013b. Prop. 1 LS Tilleg 1 (20132014): Skatter, Avgifter og Toll 2014. Oslo.

Desai M.A., Foley C.F. and Hines J.R., 2004. A Multinational Perspective on Capital Structure Choice and Internal Capital Markets. Journal of Finance 59, 2451-2487.

Dourado A. and de la Feria R., 2008. Thin Capitalization Rules in the Context of the CCCTB. Oxford University Centre for Business Taxation Working Paper 08/04.

Dreßler D., and Scheuering U., 2012. Empirical Evaluation of Interest Barrier Effects. ZEW Discussion Paper No. 12-046.

Egger P. and Wamser G., 2011. The Impact of Controlled Foreign Company Legislation on Real Investments Abroad: A two-dimensional Regression Discontinuity Design. CEPR Working Paper No. 8460, London.

Ernst\& Young, 2014. Worldwide Corporate Tax Guide 2014. EYGM Limited.

Federal Public Service FINANCE, 2012. Notional Interest Deduction: An Innovative Belgian Tax Incentive. Ministry of Finance, Brussels.

Förster G. and Schmidtmann D., 2004. CFC Legislation in Germany. Intertax 32, 476-486.

Folkvord B. and Jacobsen M.R., 2014. Corporate Income Tax and the International Challenge. Nordic Tax Journal 2014:2, 55-87.

Froot K.A. and Hines jr. J.R., 1995. Interest Allocation Rules, Financing Patterns, and the Operations of U.S. Multinationals. In: Feldstein M., Hines jr. J.R. and Hubbard R.G. (eds), The Effects of Taxation on Multinational Corporations. University of Chicago Press, 277-312.

Gouthière B., 2005. A Comparative Study of the Thin Capitalization Rules in the Member States of the European Union and Certain Other Countries. European Taxation 45, 367-451.

Haufler A. and Runkel M., 2012. Firms' Financial Choices and ThinCapitalization Rules under Corporate Tax Competition. European Economic Review 56, 1087-1103.

Herzig N., Lochmann U. and Liekenbrock B., 2008. Die Zinsschranke im Lichte einer Unternehmensbefragung Unternehmensbefragung. Der Betrieb 61, 593-602.

Hong Q. and Smart M., 2010. In Praise of Tax Havens: International Tax Planning and Foreign Direct Investment. European Economic Review 54, 82-95.

Huizinga H., Laeven L. and Nicodème G., 2008. Capital Structure and International Debt-shifting. Journal of Financial Economics 88, 80-118.

Institute for Fiscal Studies, 1991. Equity for Companies. A Corporation Tax for the 1990s. London.

Knipe P.J., Stryker J.P. and Thorne B., 2009. Earnings Stripping Under Section 163(j): Status Quo Vadis? International Business: Research, Teaching and Practice 3, 90-104.

Lodin S.O., 2014. An Overview of the Proposal of the Swedish Government Committee on Corporate Taxation. Nordic Tax Journal 2014:2, 43-54. 
Mintz J. and Smart M., 2004. Income Shifting, Investment, and Tax Competition: Theory and Evidence from Provincial Taxation in Canada. Journal of Public Economics 88, 1149-1168.

Mintz J.M. and Weichenrieder A.J., 2010. The Indirect Side of Direct Investment - Multinational Company Finance and Taxation. MIT Press, Cambridge.

Mirrlees J.A., Adam S., Besley T.J., Blundell R., Bond S., Chote R., Gammie M., Johnson P., Myles G.D. and Poterba J.M., 2011. Tax by Design: The Mirrlees Review. Oxford University Press, Oxford.

Møen, J., Schindler D., Schjelderup G. and Tropina J., 2011. International Debt Shifting: Do Multinationals Shift Internal or External Debt? Department of Economics Working Paper 2011-40, University of Konstanz.

NOU2014:13, 2014. Kapitalbeskatning i en internasjonal økonomi. Norges offentlige utredninger, Oslo.

OECD, 2013. Action Plan on Base Erosion and Profit Shifting. OECD Publishing, Paris. http://dx.doi.org/10.1787/9789264202719-en

Overesch M. and Wamser G., 2010. Corporate Tax Planning and Thin Capitalization Rules: Evidence from a Quasi-experiment. Applied Economics 42, 562-573.

Overesch M. and Wamser G., 2014. Bilateral Internal Debt Financing and Tax Planning of Multinational Firms. Review of Quantitative Finance and Accounting 42, 191-209.

Panteghini P., Parisi M.L. and Pighetti F., 2012. Italy's ACE Tax and Its Effect on a Firm's Leverage. CESifo Working Paper Nr. 3869, Munich.

Penttilä S. and Nieminen M., 2013. Finland - Interest Deduction Limitation Rules Introduced. European Taxation, May 2013, 237-242.

Princen S., 2012. Taxes Do Affect Corporate Financing Decisions: The Case of Belgian ACE. CESifo Working Paper No. 3713, Munich.
Regeringen, 2014. Summaries of the Proposal from the Swedish Committee on Corporate Taxation. http://www.regeringen.se/content/ 1/c6/24/22/09/23b369ae.pdf

Ruf M. and Weichenrieder A.J., 2012. The Taxation of Passive Foreign Investments: Lessons from German Experience. Canadian Journal of Economics 45, 1504-1528.

Schindler D. and Schjelderup G., 2012. Debt Shifting and Ownership Structure. European Economic Review 56, 635-647.

Schindler D. and Schjelderup G., 2013. Transfer Pricing and Debt Shifting in Multinationals. CESifo Working Paper Series No. 4381, Munich.

SOU2014:40, 2014. Neutral Bolagsskatt - För Ökad Effektivitet och Stabilitet. Slutbetänkande av Företagsskattekommittén. Statens offentliga utredingar, Stockholm.

Statistisches Bundesamt, 2011. Fachserie 14 Reihe 4 - Finanzen und Steuern - Steuerhaushalt. Wiesbaden.

Sylt C. and Reid C., 2011. Formula Money. Formula One's Financial Performance Guide. CNC - Communication and Network Consulting, Wyndeham Grange, Southwick, West Sussex.

US Department of Treasury, 1992. Integration of the Individual and Corporate Tax Systems: Taxing Business Income Once. US Government Printing Office, Washington.

Wamser G., 2014. The Impact of Thin-Capitalization Rules on External Debt Usage - A Propensity Score Matching Approach. Oxford Bulletin of Economics and Statistics 76, 764-781.

Weichenrieder A.J. and Windischbauer H., 2008. Thin-Capitalization Rules and Company Responses: Experience from German Legislation. CESifo Working Paper Nr. 2456, Munich. 